\title{
Supervisor Status, Health and Organizational Commitment: Mediating Role of Support and Family- friendly Policies among Information Technology Professionals in India
}

\author{
Kamala Ramadoss ${ }^{1, *}$, Megan E. Lape ${ }^{2}$ \\ ${ }^{1}$ Department of Child and Family Studies, Syracuse University, Syracuse, New York, USA \\ ${ }^{2}$ Central New York Psychiatric Center, Marcy, New York, USA \\ *Corresponding author: kramados@syr.edu
}

Received February 16, 2014; Revised February 28, 2014; Accepted March 04, 2014

\begin{abstract}
The purpose of this investigation was to examine the relationship between supervisor status on employees' health and organizational commitment as well as to assess the mediating role of supervisor support and the availability and use of family-friendly policies among Information Technology (IT) professionals in India. Using snowball technique, 359 IT professionals were surveyed from four cities in South and Western India. Structural equation modeling was done and in the initial model, supervisor status was related to organizational commitment, but not employees' health. The non-significant path was removed and the mediating variables were then included in the model. The model fit improved and was determined to be a good fit to the data. Supervisor status directly impacted two of the mediating variables - supervisor support and employees' knowledge of family-friendly policies. The direct impact of supervisor status on employees' organizational commitment was partially mediated by supervisor support. Moreover, supervisor support also directly impacted employees' knowledge of family-friendly policies and employees' organizational commitment. Employees' knowledge of family-friendly policies directly impacted employees' use of family-friendly policies and indirectly mediated the impact of supervisor status on employees' use of family-friendly policies and the impact of supervisor support on policy use. Employees' use of family-friendly policies directly and positively impacted employees' health, and indirectly mediated the impact of employees' knowledge of family-friendly policies on employees' health.
\end{abstract}

Keywords: work-family interface, supervisor status, supervisor support, software professionals, India

Cite This Article: Kamala Ramadoss, and Megan E. Lape, "Supervisor Status, Health and Organizational Commitment: Mediating Role of Support and Family-friendly Policies among Information Technology Professionals in India.” Journal of Business and Management Sciences, vol. 2, no. 1 (2014): 1-9. doi: 10.12691/jbms-2-1-1.

\section{Introduction}

In the last two decades, the Indian economy has emerged as a rising star in the Asian horizon in large part due to the remarkable achievements in the Information Technology-Information Technology enabled Services (IT-ITeS) sectory. This phenomenal growth of India's ITITeS sector in terms of expanding global reach has translated in huge gains in revenue and in creating employment opportunities. According to the National Association of Software and Services Companies, [an apex body responsible for the Information Technology Business Process Outsourcing (IT-ITeS) sector in India], by the end of 2011, the Indian IT-ITeS sectory had employed 2.8 million professionals, generating close to $\$ 100$ billion thereby contributing about 26\% of India's merchandise exports $[35,36]$. With multinational corporations and Indian organizations with a global outreach vying for skilled manpower in India, retention of talent is a serious challenge for IT-ITeS firms.

Previous research on employees in the IT-ITeS sector reported that long work hours, shift work, assuming pseudo-identities and high job demand were related to high stress and psychosomatic illnesses leading to high turnover in the Information Technology enabled Services in India $[10,33,45,58,59,60]$. Research on the antecedents and consequences of organizational commitment among software professionals in India reported that high workfamily conflict was related to high job burnout and low organizational commitment [55] and low performance orientation, high organizational deviance and low organizational citizenship behaviors [31]. This study extends previous research by examining supervisor status, employees' health and organizational commitment among employees in the knowledge-based economy in India. Furthermore, the mediating role of supervisor support, and the availability and use of work-family policies will also be examined. 


\subsection{Hypotheses}

The hypotheses of this study are as follows:

$\mathrm{H} 1$ : When employees perceive their supervisors to have higher status, they will report greater supervisor support for work-family issues.

H2: High supervisor support will be related to greater knowledge of work-family policies.

H3: High supervisor support will be related to greater use of work-family policies.

H4: Greater knowledge of the availability of work-family policies will be related to greater use of work-family policies.

H5: Greater use of work-family policies will be related to better self-reported health.

H6: High supervisor support will be related to high organizational commitment.

H7: Greater knowledge and use of work-family policies will be related to higher levels of organizational commitment.

H8: When employees perceive their supervisors to higher status, they will report higher levels of organizational commitment and better health and these relationships will be mediated by supervisor support, knowledge about availability of work-family policies and the use of workfamily policies.

\section{Literature Review}

The new economy is characterized by a dramatic shift from manufacturing to knowledge based service industry [11]. Advances in information technologies coupled with cost consciousness have led to an increase in outsourcing jobs in the knowledge based service industry from the West to the East [7]. India has emerged as a forerunner in this market by providing an attractive amalgamation of cost, quality and scalability [44].

What are the reasons for India's dominance in the global offshore IT-ITeS market? The first wave of reforms in 1991 led to the liberalization of the Indian economy; this was followed later by the second wave of reforms particularly in the highly regulated telecom industry. These economic reforms heralded the emergence of India as a preferred destination for IT-ITeS market [9]. Furthermore, State support for the IT-ITeS industry includes the setting up of Information Technology Parks or Special Economic Zones that provide location specific incentives like tax holiday, preferential treatment in the allocation of physical infrastructure such as power, water, telecom, etc. [11,36,40,44].

The labor pool in India includes an English speaking labor force and the availability of skilled labor. In particular, the availability of an English-speaking skilled labor force puts India ahead of other low-cost countries such as Brazil, Hungary, Philippines and China. Other factors including a favorable exchange rate with the dollar and the time difference between India and principal consumers in the West such as the US and UK have contributed significantly to the growth of the IT-ITeS sector in India [33,36,40,44].

The information technology sector in India is not without its challenges. The nature of the jobs in the ITITeS sector in India are very demanding; IT professionals typically work with teams aboard (which then requires them to work long hours to match international time differences), as the purpose of their work is to write pieces of computer programs that would complement the work of the parent team abroad [40]. Moreover, pay and benefits are linked to performance - employees' own performance and that of their team's. This leads to high employee turnover which is estimated to be about 15-35 percent [33,34,35,36,37].

Anecdotal and exploratory research reported the reasons for the high attrition rate in the IT-ITeS sector to be - assuming pseudo-identities, learning a foreign accent, high burnout due to the long work hours, shift work, a mis-match between work and social life, and lack of workfamily balance for employees $[11,45,53,58,60]$. Employees in the IT-ITeS industry report health issues such as gastric ulcer, hypertension, diabetes, clinical depression, spondylitis, etc. [28-64]. Human Resources personnel and Managers in IT-ITeS centers reported stressful work conditions and its effect on health as one of the major challenges faced by employees working in these centers leading to high attrition [33,34].

\subsection{Organizational Commitment and Employees' Well-being}

Reference [2] defined organizational commitment as the "psychological state that binds the individual to the organization.” According to Organizational support theory, employees have a tendency to attribute humanlike characteristics to the organization, which results in perceived organizational support. Furthermore, perceived supervisor support is perceived as organizational support [20,48,51,52]. This personification is brought about by

1. The fact that organizations assume legal, moral and financial responsibility for the actions of its agents (supervisors, managers).

2. Organizational policies, norms and culture prescribe role behaviors and provide continuity.

3. The power that agents of the organizations (managers, supervisors) have over their subordinates.

Based on this personification of the organization, employees tend to view the treatment received from the organization (both favorable and unfavorable) as an indication of how much the organization cares about the employees' well-being as also the extent to which the employee's contributions are valued by the organization. Employees, therefore, trade effort and dedication to their organization for incentives such as pay, fringe benefits, esteem, approval and caring [20]. The supervisor plays a central role as these rewards are dependent on supervisor appraisals, particularly with respect to family-friendly benefits and policies. Although organizations provide family-friendly benefits and policies to help employees balance their work and family lives [47], the use of these policies is contingent on supervisors' discretion [46].

Previous research in India on organizational commitment have reported some variables in the workplace as reduced role ambiguity [25], as well as organizational culture and the work environment $[54,55,56]$ as well as personal characteristics such as tenure [56], internal locus of control [1], status [41] to be significantly related to organizational commitment. In further exploring the role of organizational status, [59] 
reported that tenure and organizational structure were related to organizational commitment for supervisors whereas locus of control was positively related to organizational commitment for blue collar workers. All of these researches on organizational commitment were in other sectors such as manufacturing and service. In examining the work-family interface among IT professionals, [57] reported that high levels of conflict (work-to-family and family-to-work conflict) among IT professionals had negative consequences in the different aspects of their work and family lives and emphasized the need for the availability of work-family policies and programs in helping IT professionals manage their conflicting work and family demands.

\subsection{Supervisor's Role}

Due to the recent socio-economic changes, diverse family forms exist. In response to the challenges brought on by the demographic and structural changes in the family and a changing economy, organizations adopted family-friendly policies [24-42]. These family-friendly policies were designed to accommodate the needs of a diverse workforce [3]. According to neo-institutional theory [19], adopting family-friendly policies has an economic value (recruiting and retaining talented labor), and is also a means to maintaining legitimacy in a climate where incorporating family-friendly policies is normative. In this context, employers provide work-family benefits and policies to improve business efficiency [13] and to promote gender equality in the workplace [17].

Evidence suggests that adoption of formal familyfriendly policies at the organizational level does not necessarily equate to corresponding practices unless they are accompanied by a change in organizational norms and values regarding the appropriate interaction between work and family life [3-30]. For example, individuals who take advantage of family-friendly policies may face negative judgments regarding their lack of commitment to the organization $[4,5,6,7,8]$. Also, family-friendly benefits such as flexibility with respect to work hours, schedules and timing fall into the ambiguous category compared to other benefits such as health insurance or medical benefits [39]. When organizational policies are ambiguous, intraorganizational interests shape policy usage. This implies that policy usage may vary across the organization and be constructed locally by supervisors [8]. Supervisors may provide support either by the by the presence of supportive behaviors (eg. provide information, instrumental aid, mentoring) or by the absence of non-supportive behaviors (eg. prevent use of family friendly programs and benefits by employees or favor employees that do not use these programs).

Although there is ample research evidence that supervisor support is very important for subordinates' work-family issues, not all supervisors are supportive of their subordinates at all times. This is due to the dual roles played by supervisors. On the one hand, supervisors represent the organization to their subordinates and on the other hand, they are employees themselves. As agents of the organization, supervisors communicate the organization's goals and values to subordinates and evaluate subordinates' performance. Subordinates' organizational rewards (merit pay, skill training) and working conditions (greater autonomy, recognition from upper-level management) are contingent upon supervisor appraisals. According to organizational support theory, increasing supervisor support will be positively associated with increasing affective organizational commitment which would in turn have a decreasing effect on withdrawal behaviors and therefore attrition rates [21-48].

As employees, supervisors are people in the middle of the organizational hierarchy. A supervisor's upward dyadic relationship is related to their downward dyadic relationship [14,23-61]. Greater organizational support and support from managers provides supervisors with greater access to organizational resources and are also related to supervisors' ability to cut red tape, support innovation, create more opportunities and provide greater autonomy for subordinates [14,23-51]. Furthermore, [15] reported that supervisors' awareness of organizational work-life programs and instrumentality perceptions were associated with the frequency of supervisors' referrals to work-life programs. Therefore, when employees perceive their supervisor to have high status, it will be related to high levels of supervisor support for subordinates' workfamily issues which will then create a favorable environment for the use of work-family benefits and policies.

\subsection{Family-friendly Policies}

Family-friendly policies are not new in India. Policies such as the Maternity Benefits Act (1961), Equal Remunerations Act (1971) and anti-sexual discrimination policies $(1869 ; 1997)$ have been well established prior to the phenomenal growth of the IT-ITeS sector in India [47]. But the adoption of family-friendly policies such as job sharing, flex-time, telecommuting, counseling, gym and other wellness programs were first introduced by multinational corporations in the IT-ITeS sector in India [62]. Ostensibly, the goal of introducing these workfamily policies was to reduce job stress and promote gender equality [29] thereby controlling somewhat for high attrition rates (as these incentives were linked to employee loyalty); still it was the "bottom line" that was the driving force behind these policy initiatives. In a study of employees working in ITeS sector in India, [46] reported that the use of family-friendly benefits and policies was not a right or entitlement for the employee but was contingent more on the discretion of the supervisor/manager despite the fact that the use of familyfriendly policies and programs had been reported to be effective in helping employees balance their work and family lives. For example, in a qualitative study of 13 women IT professionals in India, [63] reported that the respondents were able to balance their work and family responsibilities because of the formal policies and programs (such as maternity benefits, paid leave for personal/sick leave, telecommuting, flex-time, etc.) and informal supports (such as supervisor support and coworker support) that had been available to them at the workplace.

In conclusion, it is seen that most of the research on organizational commitment in India has focused on employees in sectors such as manufacturing and service sector. There is a need to examine the antecedents of organizational commitment and wellbeing among IT 
professionals because of their unique work environment such as adoption of novel technologies, high job demand and work stress, work with teams aboard (which then requires them to work long hours to match international time differences). Although organizations provide familyfriendly policies and benefits to IT professionals in India in managing their work and family responsibilities [62], their use is contingent on a supervisor's discretion [46]. This study extends previous research by examining the relationship between supervisor status, employees' health and organizational commitment as also the mediating role of supervisor support, and the availability and use of work-family policies among employees in the knowledge based IT industry in India (Refer Figure 1 for the conceptual model).

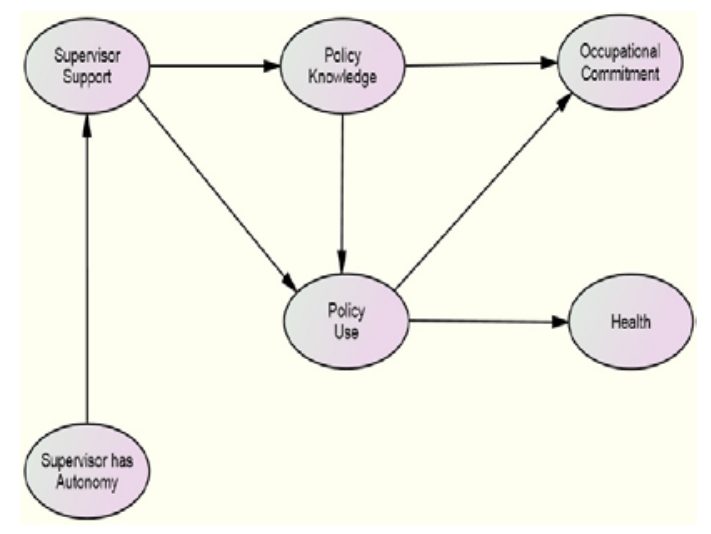

Figure 1. Conceptual model

\section{Methodology}

\subsection{Research Design}

Data for this study comes from a larger study of employees in the IT-ITeS sector in India. Human resources managers of various IT-ITeS firms in south and western India were contacted and permission to recruit participants was obtained. Due to heightened security in the IT-ITeS firms, the investigator was allowed access to the reception area and cafeteria. Research participants were recruited from the cafeteria when they were there for their break periods. Snowball technique was also used to recruit participants for the study. A total of 804 respondents participated in the study but only 774 returned usable surveys (thirty people completed only a page of the survey and could not be used in the study; as the information available was very limited it was not possible to evaluate if the people who did not complete the full survey were significantly different from those who did). The final sample for this investigation comprised of 359 individuals who self-identified themselves as IT professionals. Participants had the option to use the survey in either electronic format or paper-pencil format.

\subsection{Sample}

A majority of the respondents surveyed were male (81\%); 70\% of the respondents reported as being single, $29 \%$ reported as being married and 1\% reported as being divorced/separated. Regarding living arrangement, 19\% of the sample reported as living in extended family and $81 \%$ of the respondents reported as living in nuclear family that is, living with parents and siblings if one was single and living with spouse and/or children if one was married. This was a relatively young sample; the mean age of the respondents was 26.86 years $(S . D .=5.95)$. Total work experience reported was 3.72 years on average and tenure on the current job was 2.39 years on average. These findings are similar to those reported in the literature [6,31,32,43,55-63] wherein employees in the knowledgebased IT-ITeS Sector in India tend to be relatively young in age.

\subsection{Measures}

The measures used in this study as listed below.

\subsubsection{Supervisor Status}

Supervisor status was measured as a report of employees' perception of how much autonomy their supervisor had in the organization [21]. Response categories ranged from strongly disagree (coded 1) to strongly agree (coded 5) to the following statements - my company gives my supervisor the authority to try new things, my company supports decisions made by my supervisor, my company allows my supervisor to run things the way he/she wants, my company gives my supervisor the freedom to determine how to rate my work. A higher score indicated employees' perception that their supervisor enjoyed greater autonomy in the workplace. The mean for supervisor support was 3.19, the standard deviation was 0.90 and scale reliability was 0.80 .

\subsubsection{Supervisor Support}

A report of supervisor support for employees' workfamily issues was obtained and included items from the National Study of the Changing Workforce [22] on supervisor support for work-family issues. Response categories ranged from strongly disagree (coded 1) to strongly agree (coded 5) to the following statements - my supervisor keeps me informed of the things I need to know to do my job well, my supervisor has expectations of my performance on the job that are realistic, my supervisor recognizes when I do a good job, my supervisor is understanding when I talk about my personal or family issues that affect my work, my supervisor really cares about the effects that my work demands have on my personal and family life, my supervisor listens to me and pays attention to my ideas and concerns, I feel comfortable bringing up personal or family issues with my supervisor, my supervisor accommodates me when I have family or personal business to take care of. A higher score indicated greater supervisor support for employees' workfamily issues. The mean for supervisor support was 3.35, the standard deviation was 0.73 and scale reliability was 0.83 .

\subsubsection{Employees' Knowledge and Use of Family- friendly Policies}

The scales to measure participants' knowledge on the availability of family-friendly policies and benefits as also the usage of these policies were from the National survey of dual earner couples in the sandwiched generation [16]. This scale was then given to two Human Resources Managers and five employees working in IT-ITeS firms in India for their feedback and to include in the final list, the 
most commonly available family-friendly benefits/policies. Response categories included "yes" coded as 1 if they were aware of a particular family-friendly benefit/policy and/or if the respondent used a particular family-friendly benefit/policy. Similarly, "no" was coded as 0 if a respondent was unaware of a particular family-friendly benefit/policy and/or if they did not use the same. As there were 10 benefits/policies listed in the survey, they were added up and the total score ranged from 0-10. The mean was 6.97 , standard deviation was 3.55 , scale reliability was 0.86 for respondents' knowledge on the availability of family-friendly policies and the mean was 3.57, standard deviation was 2.39, scale reliability was 0.73 for respondents' reported use of family-friendly policies.

\subsubsection{Health}

The scale developed and standardized by [18] was used to measure employees' self-reported health. This scale was then given to two Human Resources Managers and five employees working in IT-ITeS firms in India for their feedback. The final scale included eight items related to health such as "In the past two weeks how often did you have trouble sleeping, have back pain, have severe headaches, have stomach pains due to hyperacidity or ulcer, etc.” response categories included Never (coded 1) to all the time (coded 5). The items were reverse coded so that a higher score indicated better state of self-reported physical health and well-being. The mean was 3.67, the standard deviation was 0.78 and scale reliability was 0.79 .

\subsubsection{Organizational Commitment}

A report of respondents' organizational commitment was obtained [2]. Response categories ranged from strongly disagree (coded 1) to strongly agree (coded 5) and some of the items included - I would be very happy to spend the rest of my work life with this current company, I think I could easily become attached to another company as I am to this one, I do not feel like 'part of the family' at my company, my company has a great deal of personal meaning for me, I do not feel a sense of belonging to my company, my company really cares about me, my company provides a supportive environment for workers. Some items were reverse coded such that a higher score indicated greater organizational commitment. The mean for organizational commitment was 3.29, the standard deviation was 0.61 and scale reliability was 0.76 .

\subsection{Discussion of Findings}

Data cleaning and management was done using IBM SPSS Statistics and data analysis was done using IBM SPSS Amos 19. Structural equation modeling was done to test the hypotheses. Descriptive statistics such as the means, standard deviations, reliabilities and correlations of the variables included in the study are reported in Table 1.

On average, IT professionals in India reported better health (mean $=3.67$, standard deviation $=0.78$ ) and supervisor support (mean $=3.35$, standard deviation $=$ 0.73 ) and a moderately high organizational commitment (mean $=3.29$, standard deviation $=0.61$ ) and supervisor status $($ mean $=3.19$, standard deviation $=0.90$ ). While knowledge of the availability of work-family benefits and policies was high (mean $=6.97$, standard deviation $=3.55$ ), usage of work-family benefits and policies was lower (mean $=3.57$, standard deviation $=2.39)$. The reliability coefficients of the variables included in the study ranged from 0.73 to 0.86 which meets the minimum acceptable criterion. Among the 15 inter-correlations between the variables included in the study, 3 were not significant, 2 were found to be significant $(p<0.05)$ and 10 were found to be significant $(p<0.01)$. For variables with a high correlation between them, for e.g. respondents' knowledge on the availability of work-family policies and benefits and respondents' use of work-family policies and benefits $(\mathrm{r}=.62, p<0.01)$ a test for multi-collinearity was done. As the tolerance values were in the acceptable range [38], they were included in the model.

Table 1. Inter-correlations of Variables $(N=359)$

\begin{tabular}{|c|c|c|c|c|c|c|c|}
\hline & Variables & 1 & 2 & 3 & 4 & 5 & 6 \\
\hline 1. & $\begin{array}{c}\text { Organizational } \\
\text { commitment }\end{array}$ & - & & & & & \\
\hline 2. & Health & .07 & - & & & & \\
\hline 3. & $\begin{array}{c}\text { Knowledge of } \\
\text { work-family } \\
\text { policy } \\
\text { availability }\end{array}$ & $.33 * *$ & .09 & - & & & \\
\hline 4. & $\begin{array}{l}\text { Work-family } \\
\text { policy usage }\end{array}$ & $.18^{* *}$ & $.15^{* *}$ & $.62 * *$ & - & & \\
\hline 5. & $\begin{array}{l}\text { Supervisor has } \\
\text { autonomy }\end{array}$ & $.56^{* *}$ & $.11^{*}$ & $.41^{* *}$ & $.18^{* *}$ & - & \\
\hline \multirow[t]{5}{*}{6.} & $\begin{array}{c}\text { Supervisor } \\
\text { support }\end{array}$ & $.50 * *$ & .05 & $.29 * *$ & $.13^{*}$ & $.51 * *$ & - \\
\hline & $M$ & 3.29 & 3.67 & 6.97 & 3.57 & 3.19 & 3.35 \\
\hline & S. D. & .61 & .78 & 3.55 & 2.39 & .90 & .73 \\
\hline & Range & $1-5$ & $1-5$ & $1-10$ & $1-10$ & $1-5$ & $1-5$ \\
\hline & $\alpha$ & .76 & .79 & .86 & .73 & .80 & .83 \\
\hline
\end{tabular}
employee's health mediated by supervisor support and employees' knowledge about the availability and use of family-friendly policies was assessed using AMOS 19 software package [5]. In addition to the chi-square goodness of fit statistic, the Adjusted Goodness of Fit Index (AGFI), Comparative Fit Index (CFI), and the Root Square Mean Error of Approximation (RSMEA) were used to assess model fit. RSMEA values below .08 indicate adequate parsimony in the model [27], a AGFI value over .95 indicates a good model fit [50] as does a CFI value over .93 [12].

The initial model included supervisor status as an exogenous variable and employees' organizational commitment and health as the two endogenous variables. Supervisor status was related to organizational commitment $(\beta=.39)$, but not to employees' health $(\beta=$ .10); fit indices indicated a poor initial fit to the data: $\chi^{2}$ $(23)=470.75, \mathrm{p}<.01$; AGFI $=.64$; CFI $=.42$; RMSEA $=.23$. The non-significant path was removed and the mediating variables were then included in the model. The model fit improved substantially with the inclusion of the mediating variables (supervisor support, knowledge and use of family-friendly policies) and was determined to be a good fit to the data: $\chi^{2}(18)=43.96, \mathrm{p}<.01$; AGFI = .94; $\mathrm{CFI}=.97$; RMSEA $=0.06$.

Hypotheses 1, 2, 4, 5, 6 were supported and there was partial support for hypothesis 8 but there was no support for hypotheses 3 and 7. Employees' perceptions that their supervisor had autonomy (supervisor status) was significantly related to high supervisor support (Estimate 
$=0.44, S E=0.04, p<0.01$ ) and hypothesis 1 was supported. High supervisor support was significantly related to greater knowledge of work-family policies (Estimate $=0.78, S E=0.25, p<0.01$ ) and hypothesis 2 was supported. When employees perceived their supervisor to have high levels of autonomy (supervisor status), they reported greater knowledge of work-family policies (Estimate $=1.15, S E=0.20, p<0.01$ ) and this relationship was statistically significant.

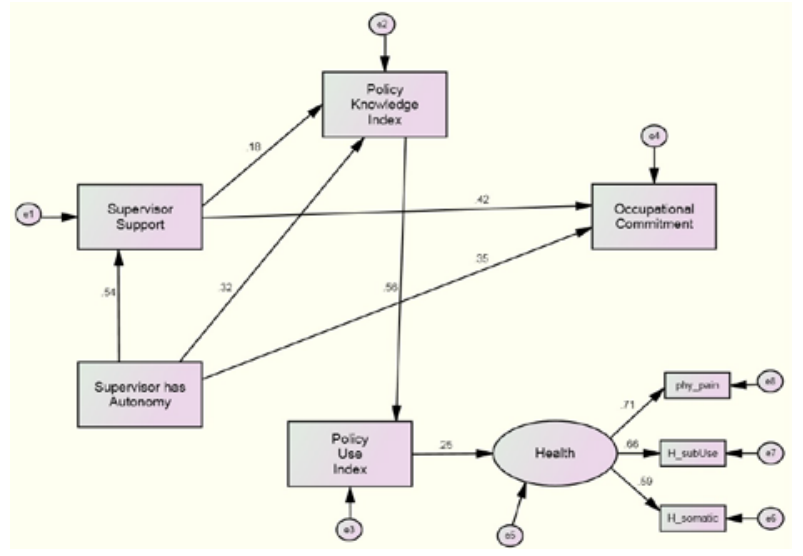

Figure 2. Impact of supervisors' autonomy and support on employees' organizational commitment and health mediated by supervisor support, employees' knowledge and use of work-family policies $(N=359)$

Greater knowledge of work-family policies was significantly related to greater use of work-family benefits (Estimate $=0.39, \mathrm{SE}=0.03, \mathrm{p}<0.01$ ) and hypothesis 4 was supported. Greater use of work-family benefits was significantly related to better health (Estimate $=0.08, \mathrm{SE}$ $=0.01, \mathrm{p}<0.01$ ) and hypothesis 5 was supported. Supervisor support was significantly related to organizational commitment (Estimate $=0.35$, SE $=0.04$, p $<0.01$ ) and hypothesis 6 was supported. When employees perceived their supervisors to have greater autonomy (supervisor status), they reported higher organizational commitment (Estimate $=0.23, \mathrm{SE}=0.03, \mathrm{p}<0.01$ ) and this relationship was statistically significant. Furthermore, supervisor has autonomy directly impacted two of the mediating variables: supervisor support $(\beta=.54)$ and employees' knowledge about availability of work-family policies $(\beta=.32)$. The direct impact of supervisor has autonomy on employees' organizational commitment was partially mediated by supervisor support $(\beta=.35 ; \Delta \beta$ $=.04$ ). There was partial support for hypothesis 8 . Also, Knowledge about availability of family-friendly policies directly impacted employees' use of family-friendly policies $(\beta=.56)$ and indirectly mediated the impact of supervisor status on use of family-friendly policies $(\beta$ $=.24$ ) and the impact of supervisor support on use of family-friendly policies $(\beta=.10)$. Employees' use of family-friendly policies directly and positively impacted employees' health $(\beta=.25)$, and indirectly mediated the impact of knowledge about availability of family-friendly policies on employees' health $(\beta=.14)$.

\section{Conclusions and Recommendations}

The phenomenal growth of the IT-ITeS sector put India on the global map and India is seen as an emerging economy. In a knowledge based industry such as the IT sector, employees are a valuable resource. Previous research on the antecedents and consequences of organizational commitment among IT professionals in India reported that high work-family conflict was related to high job burnout and low organizational commitment [55]. This study extends previous research by examining supervisor status, respondents' health and organizational commitment among employees in the knowledge-based economy in India. Furthermore, the mediating role of supervisor support, and the availability and use of familyfriendly policies was also examined.

As hypothesized, when employees perceived their supervisors to have greater autonomy (supervisor status), they reported higher organizational commitment. Moreover, the direct impact of supervisor has autonomy on employees' organizational commitment was partially mediated by supervisor support. Salience of the supervisor's role is well documented in the literature [26-55]. Reference [26] observed that frontline supervisors have a direct influence on subordinates' workload and work-related stressors, which has an impact on the extent to which a subordinate's work role interferes with his/her family role(s). Family-supportive organizational initiatives such as flexibility with respect to work hours, schedules and timing are contingent on the discretion of the supervisor. Furthermore, [55] reported that high work-family conflict was associated with low organizational commitment but social support in the workplace (including supervisor support) was found to mitigate the adverse effects of job burnout thereby leading to greater organizational commitment.

Research on supervisor status and subordinates' knowledge and use of work-family policies is sparse. In the current analysis we observed that supervisor status directly impacted two of the mediating variables: supervisor support and employees' knowledge about availability of work-family policies. When employees perceived their supervisors to have greater autonomy, they reported greater supervisor support and they were more aware of family-friendly policies and benefits. Familyfriendly benefits such as flexibility with respect to work hours, schedules and timing fall into the ambiguous category [39]. When organizational policies are ambiguous, intra-organizational interests shape policy usage. This implies that policy usage may vary across the organization and be constructed locally by supervisors [8].Similar findings were reported by [46] in a study of employees working in call centers in India, wherein they reported that the use of family-friendly benefits and policies was not a right or entitlement for the employee but was contingent more on the discretion of the supervisor/manager.

Scholars have speculated that when organizations implement offer family-friendly policies they will help employees to manage the conflicting demands of their work and personal/family life [32-57]. In the current analyses, it was observed that knowledge about availability of work-family policies directly impacted employees' use of work-family policies. Moreover, employees' use of work-family policies directly and positively impacted employees' health, and indirectly mediated the impact of knowledge about availability of work-family policies on employees' health. Similar findings were reported by [63] in a qualitative study of 13 
women IT professionals in India. They reported that the respondents were able to balance their work and family responsibilities because of the formal policies and programs (such as maternity benefits, paid leave for personal/sick leave, telecommuting, flex-time, etc.) and informal supports (such as supervisor support and coworker support) that had been available to them at the workplace.

This study is not without its share of limitations. First, measures of outcome variables need to be more nuanced. The measure of organizational commitment focused more on affective commitment than the other aspects of organizational commitment, such as, normative commitment and continuance commitment as also data on absenteeism and productivity. Future studies are needed to delve deeply into all three aspects of organizational commitment, namely, affective commitment, normative commitment and continuance commitment. Similarly, the measure of health focused on physical health. Future studies need to focus on all aspects of health, both physical health and psychological health. Second, data was collected from single informants, namely, IT professionals. Data from multiple informants such as coworkers and supervisors will enrich our understanding of the phenomenon under study because family-friendly benefits fall into the ambiguous category [39] and when organizational policies are ambiguous, intraorganizational interests shape policy usage and will be constructed locally by supervisors and co-workers [8]. Moreover, IT professionals in India work with teams abroad thereby working in a virtual environment. What is the role of this virtual co-worker support? Third, this survey used a cross-sectional research design; consequently causal statements cannot be made. Future studies need to use a longitudinal design so that causality can be established. Moreover, snowball technique was used as a sampling technique which limits generalization of results. Fourth, surveys need to be complemented with other methods of data collection such as observation, event sampling method. Fifth, future studies need to compare how supervisor support and family-friendly policy use impact organizational commitment and health for employees who are single and those who are married and have established their own families. In the current study a majority of the respondents were male and living in nuclear families, that is, living with parents and siblings if one was single and living with spouse and/or children if one was married. Unlike in the West, employees who are single in India do not live alone but continue to live with their parents and siblings. The family responsibilities and time commitment for family roles will be very different when one is living with parents and siblings versus living with spouse and one's own children and this need to be examined. Similarly, the situation of men and women will be very different and gender differences also need to be analyzed. Sixth, other sources of support that impact how one deals with stressful situations needs to be explored as they will impact one's organizational commitment and health. Particularly in the Indian context, religiosity and spirituality play an important role in one's life. Forty-eight percent of the respondents mentioned that they belonged to an organized religious group such as Saibaba, Swaminarayan sampradaya, Art of living, etc., which not only emphasize religiosity and spirituality but also provide social support for their members. Furthermore, a majority of the respondents mentioned talking to a religious leader or an elderly person (not parents) from the extended family or community as an important coping strategy in the face of adversity. The pathways through which these different sources of support (along with support at the workplace and extended family support) help employees cope with their work and family demands need to be systematically examined.

In conclusion, India has emerged as the preferred destination for the knowledge-based service sector. To be at the forefront, organizations need to focus not only on growth, development and consolidation of business but also on programs and policies that would help retain their employees. Organizational policies need to focus more on high commitment work practices that would not only increase productivity but also help employees enjoy a better quality of life. In today's global economy, work environments are highly stressful but when supervisors have greater autonomy, they are more supportive of their subordinates' work-family issues. Supportive supervisors foster increased organizational commitment and better health in their subordinates by creating an environment that fosters the use of family-friendly benefits and policies. This is an important area that needs to be researched further as understanding the antecedents and consequences of organizational commitment and employee well-being can help design interventions that will lead to a better quality of life for all employees.

\section{Acknowledgement}

This project was funded by CoHE Seed Grant, College of Human Ecology, Syracuse University, Syracuse, New York, USA awarded to Kamala Ramadoss during 2009-10. This work was done when Dr. Lape was a Graduate Assistant in the Department of Child and Family Studies, Syracuse University, Syracuse, New York, USA.

\section{References}

[1] Achamamba, B., \& Gopikumar, K. (1990). Locus of control and job involvement among men and women bank employees. Indian Journal of Applied Psychology, 27, 6-9.

[2] Allen, N. J., \& Meyer, J. P. (1990). The measurement and antecedents of affective, continuance and normative commitment to the organization. Journal of Occupational Psychology, 63, 1-18.

[3] Allen, T. D. (2001). Family supportive work environments: The role of organizational perceptions. Journal of Vocational Behavior, 58, 414-435.

[4] Allen, T. D., Poteet, M. L., Russell, J. E. A., \& Dobbins, G. H. (1997). A field study of factors related to supervisors' willingness to mentor others. Journal of Vocational Behavior, 50, 1-22.

[5] Arbuckle, J.L. (2010). AMOS 19 User Manual. Retrieved from http://www.amosdevelopment.com/download/amos.pdf

[6] Bashir, S., \& Ramay, M. I. (2008). Determinants of organizational commitment: A study of Information Technology Professionals in Pakistan. Journal of Behavioral and Applied Management, 9(2), 226-238.

[7] Batt, R., Doellgast, V., Kwon, H., Nopany, M., Nopany, P. \& da Costa, A. (2005). The Indian Call Centre Industry: National benchmarking report strategy, HR practices, \& performance (CAHRS Working Paper \#05-07). Ithaca, NY: Cornell University, School of Industrial and Labor Relations, Center for Advanced Human Resource Studies. 
[8] Blair-Loy, M., \& Wharton, A. S. (2002). Employees' use of workfamily policies and the workplace social context. Social Forces, 80, 813-845.

[9] Budhwar, P. S. (2001). Doing business in India. Thunderbird International Business Review, 43(4), 549-68.

[10] Budhwar, P. S., Varma, A., Malhotra, N., \& Mukherjee, A. (2009). Insights into the Indian call center industry: Can internal marketing help tackle high employee turnover? Journal of Services Marketing, 23(5), 351-362.

[11] Budhwar, P. S., Varma, A., Singh, V., \& Dhar, R. (2006). HRM systems of Indian call centers: An exploratory study. International Journal of Human Resources Management, 17(5), 881-897.

[12] Byrne, B. M. (2003). Structural equation modeling with EQS and EQS/Windows. Thousand Oaks, CA: Sage Publications.

[13] Carless, S. A., \& Wintle, J. (2007). Applicant attraction: The role of recruitment function, work-life balance policies and career salience. International Journal of Selection and Assessment, 15, 394-404.

[14] Cashman, J., Dansereau, F. Jr., Graen, G., \& Haga, W. J. (1976). Organizational understructure and leadership: A longitudinal investigation of the managerial role-making process Organizational Behavior and Human Performance, 15, 278-296.

[15] Casper, W. J., Fox, K. E., Sitzmann, T. M., \& Landy, A. L. (2004). Supervisor referrals to work-family programs. Journal of Occupational Health Psychology, 9, 136-151.

[16] Colton, C. L. 2004. The role of informal organizational workfamily support in the use of formal work-family supports and associated outcomes. Unpublished Dissertation. Portland, OR: Portland State University.

[17] Dreher, G. F. (2003). Breaking the glass ceiling: The effect of sex ratios and work-life programs on female leadership at the top. Human Relations, 56, 541-562.

[18] Derogatis, L. R., Rikels, K., \& Rock, A. F. (1976). The SCL-90 and MMPI: A step in the validation of a new self-report scale. British Journal of Psychiatry, 128, 280-289.

[19] DiMaggio, P. J., \& Powell, W. P. (1991). The iron cage revisited: Institutional isomorphism and collective rationality in organizational fields. American Sociological Review, 48, 147- 160.

[20] Eisenberger, R., Huntington, R., Hutchison, S., \& Sowa, D. (1986). Perceived organizational support. Journal of Applied psychology, 71, 500-507.

[21] Eisenberger, R., Stinglhamber, F., Vandenberghe, C., Sucharski, I. L., \& Rhoades, L. (2002). Perceived supervisor support: Contributions to organizational support and employee retention. Journal of Applied Psychology, 87, 565-573.

[22] Family and Work Institute. (2002). National Study of the Changing Workforce. New York City, NY.

[23] Graen, G. B., Cashman, J. F., Ginsburgh, S., \& Schiemann, W. (1977). Effects of linking pin quality on the quality of working life of lower participants. Administrative Science Quarterly, 22, 491-504.

[24] Glass, J. L., \& Estes, S. B. (1997). The family response workplace. Annual Review of Sociology, 23, 289-313.

[25] Harigopal, K., \& Ravikumar, R. (1978). Role ambiguity, role conflict and certain job attitudes. Sedme, 3, 24-40.

[26] Hopkins, K. M. (2005). Supervisor support and work-life integration: A social identity perspective. In In E. E. Kossek \& S. J. Lambert (Eds.), Work and life integration: Organizational, cultural and individual perspectives (pp. 445-467). Mahwah, NJ: Lawrence Erlbaum Associates.

[27] Hu, L. T. \& Bentler, P. M. (1999). Cutoff criteria for Fit Indices in Covariance Structure Analysis: Conventional criteria versus new alternatives. Structural Equation Modeling, 6, 1-55.

[28] Jayaswal, R. (2005). Generation Y logs out of BPO honeymoon, The Economic Times, February 14.

[29] Komaraju, M. (1997). The work-family interface in India. In S Parasuram \& J. H. Greenhaus (Eds.), Integrating work and family: Challenges for a changing world (pp. 104-114). Westport, CT: Quorum Books.

[30] Kossek, E. (2005). Workplace policies and practices to support work and families. In S. Bianchi, L. Casper \& R. King (Eds.), Work, family, health \& well-being (pp. 97-116). Mahwah, NJ: Lawrence Erlbaum Associates.

[31] Krishnan, S. K., \& Singh, M. (2010). Outcomes of intention to quit of Indian IT professionals. Human Resource Management, 49, 421-437. doi: 10.1002/hrm.20357.

[32] Madhavi, C., \& Vimala, B. (2011). A study on work related stress and work family issues experienced by women software professionals in Chennai. International Proceedings of Economic Development and Research, 12, 264-268.

[33] Mehta, A., Armenakis, A., Mehta, N., \& Irani, F. (2006) Challenges and opportunities of Business Process Outsourcing in India. Journal of Labor Research, 27(3), 323-338.

[34] Naithani, P. \& Jha, A.N. (2009). "An empirical study of work and family life spheres and emergence of work-life balance initiatives under uncertain economic scenario." Growth - MTI, Vol. 37, No. 1, pp. 69-73.

[35] National Association of Software and Services Companies. (201112). India IT-BPO Industry. Retrieved on June, 26, 2012

[36] National Association of Software and Services Companies. (2010). IT-BPO sector in India: Strategic review. Retrieved on February 26, 2010.

[37] Niharika (2008). Challenges for the Indian BPO. ICMR Case Studies and Management Resources. Retrieved September 10, 2009.

[38] O' Brian, R. (2007). A caution regarding rules of thumb for variance inflation factors, Quality and Quantity, 41(5), 673-690.

[39] Osterman, P. (1995). Work/family programs and the employment relationship. Administrative Science Quarterly, 40, 681-700.

[40] Parthasarathy, B. (2004). “India's Silicon Valley or Silicon Valley's India? Socially embedding the computer software industry in Bangalore.” International Journal of Urban and Regional Research, Vol. 28, pp. 664-685.

[41] Pattanayak, Mishra, S.K., \& Mishra, P.K. (1993). Psychological well-being and organizational commitment: A study on Public Sector. Indian Journal of Applied Psychology, 30, 24-31.

[42] Perry-Smith, J. E., \& Blum, T. C. (2000). Work-family resource bundles and perceived organizational performance. Academy of Management Journal, 43, 1107-1117.

[43] Poster, W. R., \& Prasad, S. (2005). Work-family relations in transnational perspective: A view from high-tech firms in India and the United States. Social Problems, 52, 122-146.

[44] PricewaterhouseCoopers. (2005). The Evolution of BPO in India. Retrieved on October 14, 2010 from http://www.pwc.com/en_IN/in/assets/pdfs/evolution-of-bpo-inindia.pdf.

[45] Raghuram, S., \& Weisenfeld, B. (2004). Work-nonwork conflict and job stress among virtual workers. Human Resource Management, 43, 259-277.

[46] Rajan-Rankin, S., \& Tomlinson, M. (2012). Do work-family policies really 'work'? Evidence from Indian call centers. In J. Greenhaus, S. A. Y. Poelmans, \& M. de la Heras (Eds.). New frontiers in work-life research: Visions for the future in a global world. Palgrave Macmillan: Basingstoke.

[47] Rajadhyaksha, U. (2009). Work-life in India. Executive Briefing Series. Boston College: Center for work and family.

[48] Rhoades, L., Eisenberger, R., \& Armeli, S. (2001). Affective commitment in the organization: The contribution of perceived organizational support. Journal of Applied Psychology, 86, 825836.

[49] Rhoades, L., \& Eisenberger, R. (2002). Perceived organizational support: A review of literature. Journal of Applied Psychology, 87, 698-714.

[50] Schreiber, J. B., Nora, A., Stage, F. K., Barlow, E. A. and King, J. (2006). Reporting Structural Equation Modeling and Confirmatory Factor Analysis Results: A Review, The Journal of Educational Research, 99 (6), 323-337.

[51] Shanock, L. R., \& Eisenberger, R. (2006). When supervisors feel supported: Relationships with subordinates' perceived supervisor support, perceived organizational support, and performance. Journal of Applied Psychology, 91, 689-695.

[52] Shore, L. M., \& Shore, T. H. (1995). Perceived organizational support and organizational justice. In R. Cropanzano, \& M. Kacmar (Eds.), Organizational politics, justice and support: Managing the social climate in the work place (pp. 149-164). Westport, CT: Quorum.

[53] Singh, H. (2005). Is the BPO iceberg melting under attrition heat? The Economic Times, February 10.

[54] Singh, P., \& Das, G.S. (1978). Organizational culture and its impact on commitment to work. Indian Journal of Industrial Relations, 13, 511-524.

[55] Singh, P., Suar, D., \& Leiter, M. (2012). Antecedents, workrelated consequences and buffers of job burnout among Indian software developers. Journal of Leadership and Organizational Studies, 19, 83-104 
[56] Singhal, S., \& Sood, R. (1981). Control in hospital and occupational commitment of nurses. Managerial Psychology, 2, 51-59.

[57] Srivastava, U. R., \& Srivastava, S. (2012). Outcomes of workfamily conflict among Indian Information Technology (IT) professionals. Social Science International, 28, 137-158.

[58] Subramanian, S., \& Vinothkumar, M. (2009). Hardiness personality, self-esteem and occupational stress among IT professionals. Journal of the Indian Academy of Applied Psychology, 35, 48-56.

[59] Suman, S., \& Srivastava, A. K. (2012). Antecedents of organizational commitment across hierarchical levels. Psychology and Developing Societies, 24, 61-83.

[60] Suri, S., \& Rizvi, S. (2008). Mental health and stress among call center employees. Journal of the Indian Academy of Applied Psychology, 34, 215-220.
[61] Tangirala, S., Green, S. G., \& Ramanujam, R. (2007). In the shadow of the boss's boss: Effects of supervisors' upward exchange relationships on employees. Journal of Applied Psychology. 92, 309-320.

[62] Uma Devi, S. (2002, October 26). Globalization, Information Technology and Asian Indian women in US. Economic and Political Weekly.

[63] Valk, R., \& Srinivasan, V. (2011). Work-family balance of Indian women software professionals: A qualitative study, IIMB Management Review, 23, 39-50.

[64] Wadhwa, R. (2004). Oh honey! I need a good night's sleep. The economic Times, August 14. 